\title{
Self-Sustaining, Irrigated Agriculture and Sustainability. A Study in Southern Guanajuato, Mexico
}

\author{
Davison G. Mazabel ${ }^{1}$, Alex R. Caldera² \\ ${ }^{1,2}$ Division of Social Sciences and Humanities, University of Guanajuato, Leon, Mexico
}

*Corresponding Author: Davison G. Mazabel, Division of Social Sciences and Humanities, Campus Leon, University of Guanajuato

\begin{abstract}
The purpose of this paper is to reflect upon the possibilities of building and assessment of scenarios of sustainability that the peasants who practice irrigated agriculture in Mexico have. In the first part, we introduce an approach to the evolution of the concept of sustainability, emphasizing on its social dimension, because we consider that it constitutes the backbone from which it will be possible to evaluate its feasibility in a more concrete way. The second part of the article presents an approach to the search of methodologies for its assessment in the study of systems which practice irrigated agriculture, in which it was a priority to consider the social perception.
\end{abstract}

Keywords: Sustainability; Irrigated Agriculture; Community Water Self-Management

\section{INTRODUCTION}

The studies of administration and management of irrigation systems have emphasized on the administration that is done by the State on one side, and the one done by the irrigators themselves on the other side (Palerm, 2015; Hunt, 1997; Maas \& Anderson, 1986).

This work is focused on the second type of administration, the one which is done or managed by the irrigators themselves. Particularly in those systems where self-sustaining is practiced, that is where the irrigators perform key tasks for the functioning of the systems, based on local knowledge and practices of adaptation, and taking office or public positions required to do it.

We are especially interested in studying such processes of self-sustainable irrigation systems in its relation to the presence of scenarios of sustainability, understanding the latter within a consideration that includes social components, that is situated in a territory, and from a plural framework that considers the assessment and perception of the users and the analysis from researchers.

Self-governance is understood as the set of social practices, characterized by the democratic nature of decision-making, which favors the autonomy of a "collective" in an exercise of shared power, which qualifies the social relations of cooperation between people and / or groups, regardless of the type of organizational structures or activities, since they intentionally express more horizontal social relations (Peixoto, 2004). It presents a multidimensional nature (social, political, economic and technical).

Precisely, in the search of these scenarios, this article is an invitation to reflect upon sustainability from its social component, and it offers a methodological approach to the study and social assessment of systems of irrigated agriculture in small territories.

This work raises two issues: in the first part it presents an approach to the definition and evolution of the concept of sustainability, emphasizing on its social dimension, because we consider that it constitutes the backbone from which it will be possible to evaluate its feasibility in a more concrete way. The second part of the article presents an approach to the search of methodologies for its assessment in the study of systems which practice irrigated agriculture, in which it was a priority to consider the social perception.

\section{BACKGROUND INFORMATION}

Based on the Brundtland Report (WCED, 1987) the concept of sustainable development extended as a new paradigm which alludes to meeting the needs of the current and future population, in relation to 
the use and exploitation of natural resources and their conservation. Since then, studies have been conducted on environmental sustainability in different scales or special dimensions (Winograd, 1995; Ronchi et al, 2002); furthermore, research has been done to determine the carrying capacity of ecosystems, as well as the economic feasibility of production activities.

Nevertheless, most of the evaluations indicate precarious conditions regarding preservation and conservation of the environment. Consequently, sustainability indicators have become a useful decision-making tool for national and local governments, communities and social actors.

Regarding the social dimension of sustainability as it has been defined by different authors (Azar $e t$ al, 1996; Enkerlin et al, 1997) there are only a few assessments that go beyond indicators that describe the satisfaction of basic needs, leaving other aspects of sustainable development pending or unconsidered, such as intra- and intergenerational equity, the level of social organization or the management capacity of a community or region, the shaping of social networking, social and human capital and the response and organization of society facing market structures and its processes of change.

During the last two decades there has been a considerable interest on the topic of collective action and its relation to the administration and sustainable management of natural resources; in that sense, we want to highlight the works of Ostrom (2000) and Ahn (2003) who, around the debate on the tragedy of the commons, postulate that, in many cases, the public goods and resources of common use can be managed in a collective way without letting it come to environmental degradation because of this.

Ostrom (2000: 26-27) has pointed out that the expression "the tragedy of the commons" has symbolized the degradation of the environment, which can be expected whenever a large amount of individuals use a scarce resource at the same time; however, Ostrom says that in different studies conducted in different regions and countries around the world, it is recognized that the increase of institutional capital is derived from collective action, moreover it is argued that social capital -based on reciprocity, trust, collaboration and the importance of sharing a common future- is a platform over which there can be built bigger and complex institutional agreements. Ostrom draws this conclusion from the analysis of various cases of organizations that manage resources of common use, and which could be extended or applied to water management for agricultural irrigation (Ostrom, 2000; Mazabel \& Romero, 2010).

\section{MATERIALS AND METHODS}

This research has considered diverse methodologies for evaluation of sustainability, that have been designed for the study of rural agro-ecosystems and that have been used in many studies conducted in Mexico and Latin America, mainly around the Marco de Evaluación de Sistemas de Manejo de Recursos Naturales incorporando Indicadores de Sustentabilidad -MESMIS- (González et al, 2006; Masera \& López-Ridaura, 2000; Astier \& Hollands, 2005; Astier, Masera \& Galvan, 2008; Speelman et al, 2007).

This methodological framework draws from considering sustainability as a set of systemic attributes defined as: productivity, stability, resilience, reliability, self-reliance and self-management. Such framework allowed us to conduct a comparative study of two irrigated agriculture systems in the south of the State of Guanajuato, specifically in the municipality of Tarandacuao (Map 1).

For the implementation of this study, there were semi structured interviews applied to users and agricultural producers of the systems, as well as to relevant community actors who hold or have held offices, or who have recognized leadership within the community.

MESMIS provides a methodological reference framework which allows to compare two rural systems (alternative or modified and traditional) in which specific managements of production and/or exploitation of natural resources in a territory are shared, in a same spatial scale, and in which its evaluation includes both external valuators (researchers) and internal (users or producers who are directly involved in the functioning of the systems.

Indicators that could describe through a qualitative scale (high, medium, low) according to the diagnostic criteria of the sustainability attributes stated in the MESMIS were developed. 


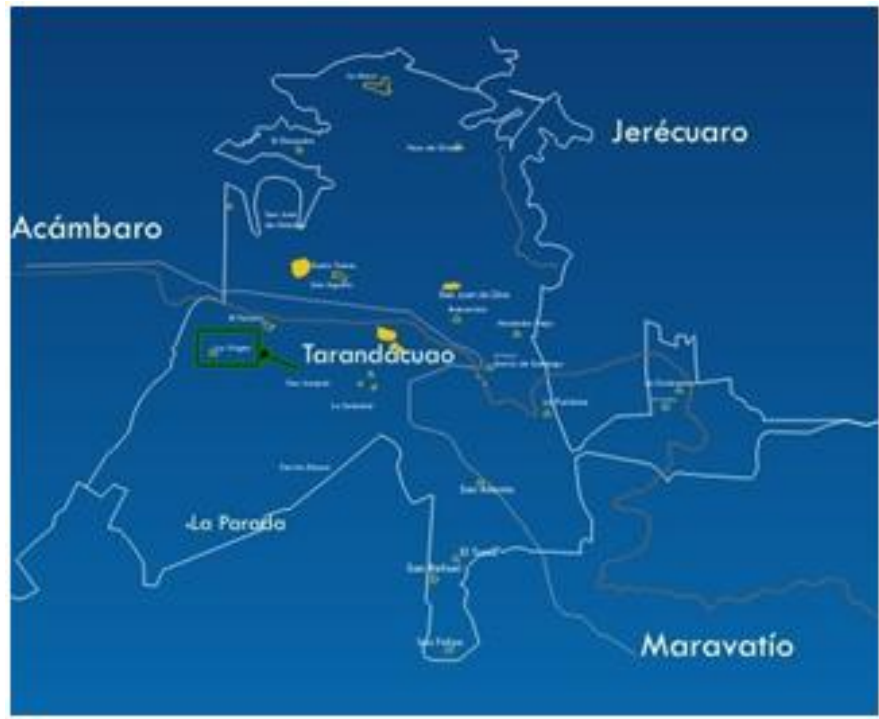

Map1. Municipality of Tarandacuao

Source: Municipality Government Tarandacuao 2009-20102

The systems of irrigated culture in consideration are:

\subsection{Alternate or Modified System.}

The irrigation system of Ejido de La Virgen is presented as alternative for having experimented technical modifications over time, especially in the last ten years (tubing, canalization and diverse associated projects) in it, traditional practices are intermingled with others coming from innovative experiences, sometimes with the support of advisors or external institutions or, other times, promoted by the areas of rural development in the municipal government. It is a system in which each of the produces has an active role in agricultural experimentation and in the introduction of crops or improved varieties which could be profitable, which is the case of the strawberry, that has had very good results in this locality. In this system, corn, sorghum, chilaca and vegetables are also cultivated.

This irrigation system is located to the west of the municipal capital, next to the AcámbaroTarandacuao highway. The members and inhabitants of this ejido were relocated by quotas to farmers to this place, since they were originally located in the village of Curinhuato, Michoacán. It's a community with indigenous purépecha origin, which has influenced their schemes of collective organization, even though there is certain migratory mobility to the United States. The ejido is formed by 53 ejidatarios (they possess the land under the form of social property), it has a gravity-driven water supply, coming mainly from Presa Santa Inés to irrigate 200 hectares.

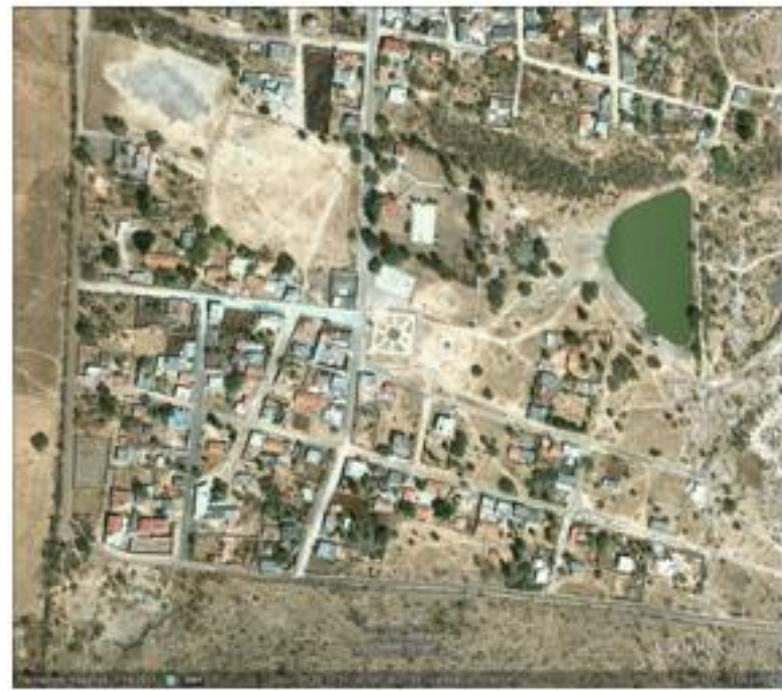

Map2. Location of Ejido de La Virgen

Source: GoogleEarth.com 
The water from which the dam is supplied comes from the run-off waters in the raining season, and it originates from the hills surrounding the dam. It is worth mentioning that, in addition to this water, the system obtains its water supply from a groundwater well that was drilled rigorously for this purpose.

In the year of 2004, they created a Civil Association known as Unidad de Riego Santa Inés, oriented to the protection, conservation, restoration, recovery and exploitation of Santa Inés Dam, whose water resource is shared with two other communities: Arroyo de la Luna y Santa Inés, which belong to the adjacent municipality of Acambaro.

\subsection{Traditional System}

The irrigation system in Ojo de Agua de Tarandacuao in its left branch and which supplies water for irrigation by gravity to the small property of the communities of Tarandacuao (municipal capital), San Juan and Buenavista. This system provides water to 98 users (smallholders or private property) who have a surface of 100 hectares, which are distributed individually or by family in parcels that go from half hectare to four and a half hectares.

The irrigation system in Ojo de Agua de Tarandacuao has been considered as traditional for being the oldest and providing water only by gravity; in the context of this system there have been typical agricultural practices of the region used and the adaptations have been done here based on a long agricultural and water management experience.

The system is located to the north of the municipal capital and in it there is cultivation of sweet potato, peanut, pepper, corn, alfalfa, broad bean, bean, a little strawberry (compared to other agroproductive systems in the region, courgetti, coriander, sorghum and vegetables.

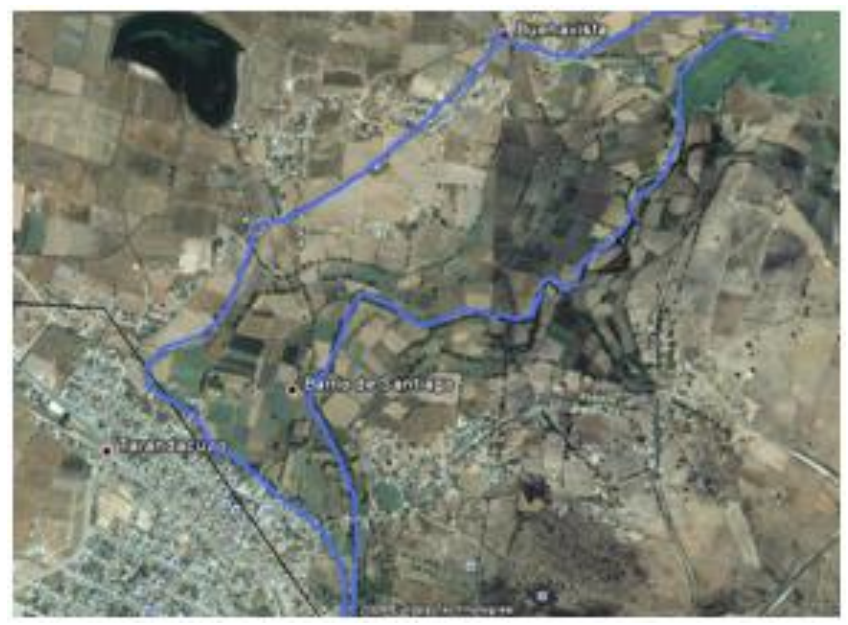

Map3. Location of the Traditional System

Source: GoogleEarth.com

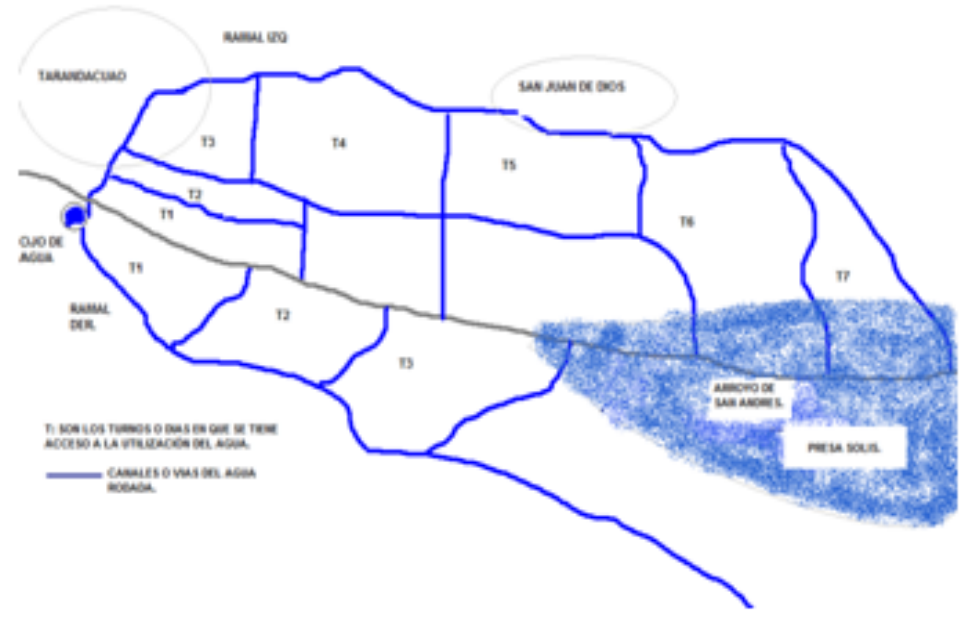

Map4. Distribution of water for irrigation network

Source: Elaborated by the author. 


\subsection{Critical Points of the Systems}

\subsubsection{Discontent of the Producers because of the Lifestyle and the Work Done in their Unidades Rurales De Produccion URP (Agrarian Production Units)}

The work is extenuating because it requires getting up at dawn or very early in the morning to look after the animals (mainly pigs, hens and turkeys) as well as to perform different agricultural activities according to the time of the year; they don't have rest days or a vacation period.

For the implementation of irrigation, they must clear the channels, open the floodgates of hydrant and control the flow of the water, which means that the peasants must endure low temperatures during the night or dawn and high temperatures during the day.

Furthermore, there are discriminatory attitudes from some of the population of the urban area, who assign the peasants a low social status, which, along with the unemployment in the region, makes that on occasions, different members of the family migrate, affecting with that the availability of labor in each of the systems.

\subsubsection{Shortage of Manpower}

Because of the emigration, manpower is short sometimes and according to the producer that is costly, however for the laborer the payment is very low, and they cannot buy a lot with what they get paid.

In general, the producers say that the laborer may be right but the fall in the corn grain prices does not allow for a wage improvement. The situation is better in the case of the producers of strawberry and consequently for the owners (ejidatarios) in the alternative or modified system that recently take part in this activity. One of the limitations of the manpower payment resides in the constant increase of the costs of agricultural inputs, especially fertilizers.

\subsubsection{Scarcity of the Water Resource}

The need for a larger amount of water to irrigate more land is reiterated among all the producers.

In the case of the irrigation system in Ojo de Agua de Tarandacuao, the decrease of water was notorious, because part of the capacity of the Ojo de Agua (water source) was channeled for the sourcing of potable water to the municipal capital.

In general, for all the municipality, namely for all the agricultural production systems there are limitations in the use of water because of the condition that the opening of new dwells for the extraction of underground water in the territory is forbidden by decision of Comisión Nacional del Agua (CONAGUA).

\subsubsection{Seasonality}

The abundance of a product by crop and its availability in the market impacts the price of the products directly; thus, the production of vegetable cultivations, which has been one of the alternatives for agricultural producers, in some occasions, has not been as profitable when there is an increase in production. That is why the producers sometimes decide they rather bet on the corn and sorghum, which have maintained relatively regular prices during the last years.

\subsubsection{Problems caused by Natural Events}

The frosts, hail and wind affect all the producers equally, both grain and vegetable cultivation producers. We could even add that an excess in rain could particularly affect those corn producers who planted in lands with insufficient drainage. When these contingencies occur excessively they affect the development of cultivations and therefore the producers who do not have insurance against this kind of damage, thereby the risk of the effects of these setbacks is taken on.

\subsubsection{Problems to Commercialize Corn}

The liberation and subsequent decrease in the prices of grains, as well as the increase in the prices of agricultural inputs (especially the industrial chemical types) and of labor -sometimes scarce- that must be hired, hinder the sale of this product, given that the buyers demand a grain of good size and color, that doesn't have signs of damage and they also seek to pay a low price for it. 


\subsubsection{Problems to Carry Out Management and to Obtain Funding}

There is a lack of knowledge regarding programs and institutions that offer consultancies or even endorsements for agricultural work. There is a need for human resources capable of carrying out procedures before public and private entities. This issue turns out to be one of the main weaknesses of the traditional system.

The irregularities in land titles that at times limit the possibility of receiving supports through programs -such as the one from Insumos Agrícolas- or to obtain funding, are problems that mostly affect the traditional system.

\subsubsection{Environmental Damage and Sanitary Risks}

During the last decades, there has been an increased recognition of the secondary and/or harmful effects that the excessive use or inadequate handling of aero chemicals such as herbicides, pesticides, fertilizers and certain types of compost and even the use of certain types of transgenic seeds in the ecosystem, the ground, water, as well as the health of agricultural workers who are exposed when they have contact with these materials.

The presence of these materials used as inputs for agricultural production is not strange to the region, where, by contrast, they are agents of persistent pollution to those who have not received adequate attention yet.

\subsubsection{Dissenting Leadership}

In the irrigation system in Ojo de Agua there have been several crisis situations because of lack of initiative, ideas and convening power, which is reflected on the fact that in many occasions there are not defined objectives, except for rare cases in the top-level of the association, in which the treasurer could be performing various functions, but it is notorious that there is a lack in leadership to convene.

There is a history of interference over the territory, that perhaps could be expressed in certain deterritorialization as a result of the construction, installation and functioning of the Solís Dam, which is why many peasants were dispossessed of their lands in the past -by decree- y and successively de facto, continued happening -now without compensation- when the level of the dam is exceeded and it floods great extensions conformed by countless parcels of peasants that have lost hope that one day this will be modified.

In the traditional system, in aspects such as the charging of fees there are collection problems that have been increasing over time.

On the other hand, in the case of El Ejido de La Virgen, there is a better organization, which has been translated into the participation in different productive projects and projects of improvement of the irrigation system, such as the channeling of a big part of it and in the maintenance of the dam, mainly in the handling of sediments. This has not only benefited the users of this system, but also the other communities that benefit from the water resource of Santa Inés Dam and with which they have undertaken strategies for local rural development.

\subsubsection{Community Participation}

In the irrigation system in Ojo de Agua de Tarandacuo there is little attendance to meetings or assemblies in which decisions are made, this limit the possibility of solving problems related to the adequate functioning of the system and which could therefore help solve major scale problems for the communal life.

On the contrary, in El Ejido de La Virgen, the participation of the community and users is more notorious and decisive since, in the assemblies, they decide permanently on different aspects related to the functioning of the irrigation system and other different community matters, besides the participation that the users of the system have in the dynamics of the Civil Association "Unidad de riego Santa Inés".

\subsubsection{Indebtedness and Problems for Collection of Fees}

The indifference of some people towards the aims of collection or recovery is notorious in the traditional system, where it turns out there are users who do not pay their share of the fees according to the land they irrigate and they take even less interest in the problems that come up, which affects 
the collection purposes and therefore the actions of functioning and maintenance of the system; this situation has propitiated scenarios of suspicion and apathy when the ones who make the contributions see that others do not. On the other hand, in the alternative or modified system, the contributions are made according to what was agreed.

\subsection{Selection of Criteria and Indicators}

The diagnostic criteria were determined, and the strategic indicators were derived based on the information provided by the producers themselves.

For this study, the following diagnostic criteria and the following indicators were defined.

\subsubsection{Social Vulnerability}

It can be defined as the possibility of a system being affected by aspects or situations that are external to the system, mainly affecting its members for which the following indicators were proposed: Availability of free time, Permanence of the producers in the system, Quality of life and Importance of the community social capital.

\subsubsection{Fragility of the System}

This diagnostic criterion considers the internal aspects of the system, such as different problems between users and the resolution of these situations, for which the following indicators have been considered: Conflict resolution mechanisms, agricultural jobs generated by the unit rural production $U R P$.

\subsubsection{Proposals to Solve Existing Problems in the System}

The elaboration of this type of proposals is possible when there is leadership, which is a condition that can be defined as the ability to influence the members of a group in a given situation, moment or circumstance (Stoner et al. Cited by Torres, $2000: 57-59$ ); It is related to the existence of individuals who have certain skills, aptitudes and attitudes, which allow them to visualize what others do not perceive at a given moment, which allows them to possess certain credibility. For which the following indicators are proposed: Existing leadership in the system and Level of presence of the water committee.

\subsubsection{Proration of the Water Resource}

It can be defined as the capacity of the system so that users as members of a community have access to water. Taking as a starting point that, in principle, water is a good or resource of common use, according to Dávila (2006), for which the following indicator is proposed: Ease of access to water in the system.

\subsubsection{Control over the System}

This criterion addresses the control that must be exercised over the activities and situations that could occur or take place and that could affect the system itself, for which the following indicators have been proposed: Existence of strategies to overcome critical aspects around to the water source and Environmental vision in the short, medium and long term.

\subsubsection{Ability to Change and Innovate}

The studied systems are constantly changing or experimenting an adaptation process to the different situations that they face, where a single objective can be reached using several strategies. For which the following indicator is proposed: Assimilation of innovations.

\subsubsection{Environmental Vulnerability}

With this diagnostic criterion, an attempt is made to characterize the dependence of systems on inputs or external resources that may generate situations of environmental vulnerability or sanitary risk. For this reason, it has been considered important that the action of these agents can be recognized by users and researchers. As an indicator we propose: Autonomy regarding inputs and Resources external to the management system.

\subsubsection{Participation in Decision Making}

It can be defined as the ability of the system to include most of its members in the management decisions that may exist for the future of said system. For which the following indicator is proposed: Democracy and participation for decision making within the system. 


\subsubsection{Community Organization}

The organization within the groups is the basis for these to work or to develop; It is argued that technological innovations alone do not work, social organization is necessary. For this, the following indicators are proposed: Access to credits, insurance or other mechanisms to obtain resources and Security of the producers based on official documents.

\section{INTEGRATION OF RESULTS AND DISCUSSION}

At this point in the process the results obtained by indicator are exposed, based on which the irrigation systems can be compared, as well as pointing out the attributes of sustainability and detecting strengths and weaknesses of each of the systems.

Table1. Levels of social indicators evaluated in the studied water systems

\begin{tabular}{|l|l|l|}
\hline \multicolumn{1}{|c|}{ Indicator } & Traditional system & Alternative or modified system \\
\hline 1- Availability of free time. & Medium & Medium \\
\hline $\begin{array}{l}\text { 2- Permanence of the producers in the } \\
\text { system. }\end{array}$ & Medium & Medium \\
\hline 3- Quality of life. & Medium & Medium \\
\hline $\begin{array}{l}\text { 4- Importance of the community social } \\
\text { capital. }\end{array}$ & Low & High \\
\hline 5- Conflict resolution mechanisms. & Medium & Medium \\
\hline $\begin{array}{l}\text { 6- Agricultural jobs generated by the unit } \\
\text { rural production URP. }\end{array}$ & Medium & Medium \\
\hline 7- Existing leadership in the system & Low & High \\
\hline 8- Level of presence of the water committee. & Low & High \\
\hline 9- Ease of access to water in the system. & Medium & Medium \\
\hline $\begin{array}{l}\text { 10-Existence of strategies to overcome } \\
\text { critical aspects around to the water source. }\end{array}$ & Low & Medium \\
\hline $\begin{array}{l}\text { 11-Environmental vision in the short, } \\
\text { medium and long term. }\end{array}$ & Low & Medium \\
\hline 12- Assimilation of innovations. & Medium & High \\
\hline $\begin{array}{l}\text { 13- Autonomy regarding inputs and } \\
\text { Resources external to the management } \\
\text { system. }\end{array}$ & Medium & Medium \\
\hline $\begin{array}{l}\text { 14- Democracy and Participation for } \\
\text { decision making within the system. }\end{array}$ & Low & Medium \\
\hline $\begin{array}{l}\text { 15- Access to credits, insurance or other } \\
\text { mechanisms to obtain resources. }\end{array}$ & Low \\
\hline $\begin{array}{l}\text { 16- Security of the producers based on } \\
\text { official documents. }\end{array}$ & Low & \\
\hline
\end{tabular}

Source: Systematization Indicators. August 2017 - January 2018.

The table highlights important differences between the systems compared, in the following indicators: the importance of community social capital, the presence of the water committee, the level of leadership, existence of strategies to overcome critical aspects around the water source, environmental vision in the short, medium and long term, the assimilation of innovations, democracy and participation in decision-making, access to credits, insurance or other mechanisms to obtain resources, as well as in the security of producers based on official documents.

In the traditional system, there are large limitations that correspond to the indicators: Importance of community capital; existing leadership in the system; degree of presence in the water committees; existence of strategies to overcome critical aspects around the water source; environmental vision in the short, medium and long term; democracy and participation in decision-making; access to credits, insurance or other mechanisms to obtain resources, and in the security of producers based on official documents. Eight indicators which presented a low level. An important aspect to point out here is that most of them translate into priority social problems and provide evidence of a deterioration of the social conditions of sustainability recognized in this system a decade ago (Mazabel, Romero \& Hurtado, 2010). In the rest of the indicators, in a total of eight, the levels obtained are locally acceptable. 
For their part, in the alternative or modified system of Ejido de La Virgen, the obtained results contrast with the previous system, obtaining a total of eleven indicators at a medium or acceptable level and five at the optimum level. Highlighting in this system a tendency to decrease in the indicator: permanence of producers in the system, mainly due to the recent migratory dynamics that has been generated within the municipality and that is also beginning to be noticed in the community.

\subsection{Integration of Indicators by Sustainability Attribute}

\subsubsection{Productivity}

The productivity levels are similar in both systems in terms of common products in the region (sorghum and corn). Some advantages are perceptible in the production of vegetables but specially in the production of strawberries in the case of agricultural production of the alternative or modified system, as well as in the case of sorghum. The phenomenon of migration is present and notoriously affects the workforce of the municipality and the region in general.

The production carried out in both systems is not notably surplus, particularly for the traditional system in which irrigation is used to produce self-consumption food or for the sale of some surplus and thus obtain resources for the needs that come up. In the case of the alternative system, in Ejido de La Virgen, a part of the production is for commercialization, mainly in the case of sorghum, some vegetables and in the case of strawberries in which some producers are participating, but with the expenses of inputs, labor and the seasonality of the prices in the region, the profits are reduced, although in financial terms, the agricultural company turns out to be more competitive in this system.

\subsubsection{Stability}

The modified system is more stable than the traditional one, although in the first one the users have the communication channels permanently open. Also there is a high degree of awareness that the failure to comply with the quotas and the regulations affects the system as a whole, and the participation of users is much more notorious, that is to say that in terms of water exploitation a commitment is assumed to be a collective enterprise, an aspect that allows them to have permanent access to the water resource, with the premise that they have to meet the corresponding quotas.

In the irrigation system of the left branch of the water source of Tarandacuao or traditional there are problems and conflicts that have been dragging on for some time, but these are usually solved by the committee. However, we must clarify that in general there are no conditions in either of the two systems to create permanent and stable jobs.

\subsubsection{Resilience}

In general, both systems, although with changes, transformations and at some point, limitations in the extraction or reduction of water availability, have upheld to a certain extent their production processes and productive and exploitation practices.

The irrigation system of the left branch of Ojo de Agua has suffered serious disturbances in terms of land and water. In past decades in terms of the loss of land due to the construction and installation of the Solís Dam and later with the floods, the water mirror has advanced over considerable tracts of land, altering the agricultural production of several users or members of the traditional system, as well as in most of the localities surrounding said dam.

Regarding the supply of water resources, particularly in terms of water source, the traditional system saw its availability reduced when part of the flow was diverted for potable water in the municipal capital. However, there is a long experience and extensive knowledge of the management of water resources, as well as of the topography of the land and the characteristics of the land for agricultural production.

Recognizing the above, the processes of strengthening social organization and the creation of new leaderships seem urgent for the consolidation of processes that are within the framework of sustainable development.

The alternative or modified system of Ejido de La Virgen has advantages in terms of the users organization, administration and profitability that the system provides or could provide and its articulation with the community processes, however, adequate consultancy and monitoring will be necessary with regard to the application, use and management of the products and waste of the 
different agrochemicals, the dependence on inputs for production is marking a high vulnerability in the system that must be addressed in the short term.

\subsubsection{Reliability}

Both systems have reliability. So far it seems that the extraction of water resources has not exceeded dramatic levels, the moderate size of the population and the provision of water in the territory, give the municipality comparative advantages at the regional level. The producers have managed to adapt their production systems to the availability offered by irrigation and they have complemented it with backyard economy and have maintained their living standards.

In recent years the grains have kept guarantee prices, so there is a minimum of confidence in cereal production in both systems, but not in vegetables where there is a certain risk, however, sometimes it is worth running. The production of the strawberry offers advantages to be considered one of the best in the region for the quality of the land and water.

\subsubsection{Adaptability}

The two systems have shown a level of adaptability, with some historical contingencies and whatnot, but they have been able to modify and create strategies in times of crisis.

They have made various adaptations since a long time ago, such as in technification (use of machinery, irrigation systems and agrochemicals), in the use of new production strategies with the introduction of improved varieties, and changes in the destination of production (self-consumption to market and vice versa), they have supported complementary economies such as backyard, among others. Notoriously more sustained in the alternative or modified system during the last decade.

\subsubsection{Equity}

The two systems tend to be equitable, however in the alternative or modified system, users have had more benefits from PROCAMPO, of agricultural supplies and access to water saving technologies, unlike the traditional system in which sometimes deprives immobility between some of the users of the system due to lack of interest or because they feel less committed, besides they have a gravity water management system for the proration of the water resource.

\subsubsection{Self-Reliance (or Self-Management in Social Terms)}

The modified system of Ejido de La Virgen has turned out to be more self-reliant because it has shown certain effectiveness -they have taken advantage of the technical assistance programs as well as the material supports- and efficiency in the management and use of water for agricultural production and they have developed their networks to a greater extent, which contributes significantly to social capital. They have greater certainty in terms of revision and validity of property titles.

The traditional system has sought to participate more in the support of material resources, neglecting other types of assistance, such as training, consultancy and technical assistance, precisely because of their lack of interest; however, they have a stable system that could allow them, if strengthened, to develop greater democratic participation, as well as an equitable proration of resources and obligations.

\section{Conclusions}

The two irrigation systems that were studied have a certain stability over time, which in our opinion could provide strength for the promotion of sustainability scenarios. In both systems, the predominant crops continue to be corn, sorghum and recently vegetables, because they offer them relative advantages that they have taken advantage of.

Based on the indicators used, it is concluded that the alternative or modified system presents higher levels of sustainability, since five of its indicators are located at a high level and eleven at an average level of the sixteen indicators; In contrast, the traditional system only obtained a total of eight indicators at a medium level, while the others were located at a low level.

It is important to reiterate that although some of the indicators point to favorable trends around social sustainability and that in turn manifest themselves in the stability of these systems, it is evident that there is a need for these systems to build or improve their organizational forms in a way that allows them to overcome the different problems mentioned and that were detected through the evaluationobservation of the sustainability indicators. 
Even though for many sociologists and development theorists, the creation of peasant and cooperative organizations have not always led to the desired results and that many of them have resulted in long processes of attrition and futility, we consider that they continue to be one of the better alternatives for the improvement of farmers' living conditions.

It is recognized that, still, in both systems, there are deficiencies in the development of skills and abilities, both economic and technical, for the sale and appropriate merchandising, at least at the regional level, of the different surplus products.

The dependence of farmers on the use of agrochemicals and technology in the region since decades ago poses important challenges for strengthening the sustainability of the systems. Therefore, it is necessary to make this circumstance more visible, from which, the farmers themselves could undertake development strategies that allow for a change in some of the limitations that conventional production has (Bustamante, Carrera \& Schwentesius, 2017; Gomez et al, 2005).

In the same way that it is recognized by González et al. (2006), it is important to point out that the bias that apparently appears in the construction and selection of the different indicators of sustainability, concerns social values and human needs. The important issue will rather be to define or recognize what is the orientation in the construction of these indicators, if it is to raise a minimum level of conditions that allow to speak of human viability or to recognize or incorporate the need to create the conditions for social and natural environment that is diverse from which human potentialities can be developed in harmony and synchrony with the environment.

Finally, we believe that it will be necessary to further explore the contributions of the studies conducted by Ostrom (2000) and that focus on the analysis of institutional arrangements that favor a kind of water management and usage that favors local sustainability scenarios; as well as the works of Palerm $(2005,2004)$ that focus on organizational design and that analyze the success or failure factors of organizations of users.

\section{ACKNOWLEDGEMENT}

This research had received the financial support of the Consejo Nacional de Ciencia y Tecnologia de Mexico, CONACYT.

\section{REFERENCES}

[1] Astier M. \& Hollands, J. (2005) Sustentabilidad y campesinado. Seis experiencias agroecológicas en Latinoamérica. Mundiprensa-GIRA-ILEIA, México D.F. pp. 262.

[2] Astier, M., Masera, O. \& Galvan, Y. (coordinadores) (2008) Evaluacion de sustentabilidad. Un enfoque dinamico y multidimensional. ECOSUR / UNAM / GIRA, pp. 1-200.

[3] Azar, C., Holmberg, J. \& Lindgren, K. (1996) "Socioecological indicators for sustainability". Ecological Economics 18, pp. 89-112.

[4] Bustamante, T., Carrera, B. \& Schwentesius, R. (2017) "Sostenibilidad de pequeños productores en Tlaxcala, Puebla y Oaxaca, México". Estudios Regionales en Economía, Población y Desarrollo. Cuadernos de Trabajo, núm. 37, ene.-feb. 2017.

[5] Dávila, S. (2006) El poder del agua ¿Participación social o empresarial? México, experiencia piloto del neoliberalismo para América Latina. México, Editorial Ítaca, pp.1-320.

[6] Enkerlin, E., Cano, G., Garza, R., \& Vogel, E. (1997) Ciencia ambiental y desarrollo sostenible. México, International Thomson.

[7] Gómez, L., Martin, L., Gómez, M., \& Mutersbaugh, T. (2005). "Certified organic agriculture in Mexico: Market connections and certification practices in large and small producers", in Journal of Rural Studies Vol. 21, No.4, pp. 461-474.

[8] González, C., Rios, H., Brunett L., Zamorano S. \& Villa, C. (2006) “¿Es posible evaluar la dimension social de la sustentabilidad? Aplicacion de una metodologia en dos comunidades campesinas del valle de Toluca", Mexico, Convergencia, revista de ciencias sociales, ISSN 1405-1435, UAEM, Mexico, eneroabril, núm. 40, pp.107-139.

[9] Hunt, R. (1997). [1988] "Sistemas de riego por canales: tamaño del sistema y estructura de la autoridad". In J. Palerm-Viqueira (Ed.), Antología sobre pequeño riego. México: Colegio de Postgraduados, Vol. 1, pp. 185-219.

[10] Maass, A., \& Anderson, R. L. (1986). [1978] ... and the desert shall rejoice. Conflict, growth and justice in arid environments. Cambridge: MIT Press, pp. 1-447. 
[11] Masera, O. \& López-Ridaura, S. (2000) Sustentabilidad y manejo de recursos naturales. México, Mundiprensa, Grupo Interdisciplinario de Tecnología Rural Apropiada (GIRA), pp. 1-96.

[12] Mazabel, D. \& Romero, M. (2010) La dimension social de la sustentabilidad en sistemas hidroagricolas. Mexico: Universidad de Guanajuato, pp. 1-110.

[13] Mazabel, D., Romero, M. \& Hurtado, M. (2010) “La evaluación social de la sustentabilidad”. Revista Ra Ximhai, vol. 6, num. 2, pp. 199-219.

[14] Ostrom, E. (2000) El gobierno de los Bienes Comunes. La evolución de las instituciones de acción colectiva, México, CRIM-UNAM / Fondo de Cultura Económica, pp. 1-64.

[15] Ostrom, E., \& Ahn, T. (2003) "Una perspectiva del capital social desde las ciencias sociales: capital social y acción colectiva" (A Social Perspective on Social Capital: Social Capital and Collective Action. (Spanish translation by Cecilia Olivares), Revista Mexicana de Sociología 65(1): pp. 155-233.

[16] Palerm, J. (2015) El auto-gobierno de sistemas de riego. Caracterizacion de la diversidad. Academia de Ciencias Exactas, Fisicas y Naturales. Bogota, D.C., pp. 1-141.

[17] Palerm, J. (2005) "Organizaciones autogestivas para el manejo del agua", Primer congreso latinoamericano de Antropología, Rosario, Argentina, Asociación Latinoamericana de Antropología.

[18] Palerm, J., Rivas, M., Ávalos C. \& Pimentel, J. (2004) "Capacidad autogestiva para la administración de sistemas de riego: la teoría y problemáticas externas”, en Jiménez, B. y L. Marín (eds.) y Morán, D., Escolero, O. y J. Alcocer (coord.) El agua en México vista desde la Academia, Academia Mexicana de Ciencias, pp. 371-387.

[19] Peixoto de Albuquerque, P. (2004) “Autogestión”, en: Cattani, A. et al. La otra economía, Universidad Nacional de General Sarmiento / Fundación OSDE. Argentina, pp. 39-46.

[20] Ronchi E., Federico, A., \& Musmeci, F. (2002) "A system oriented integrated indicator for sustainable development in Italy". Ecological Indicators, 2, p. 197-210.

[21] Speelman, N., Lopez-Ridaura, S., Aliana, C, Astier, M., \& Masera, O. (2007) Ten years of Sustainability Evaluation using the MESMIS Framework: Lessons Learned from its Application in 28 Latin American Case Studies. International Journal of Sustainable Development and World Ecology, 14: 345-361.

[22] Torres, H. (2000), Introducción a la administración, México, Trillas, Instituto Tecnológico de Estudios Superiores de Monterrey, Universidad Virtual, pp. 56-57.

[23] Winograd, M. (1995) Indicadores ambientales para Latinoamerica y el Caribe: Hacia la sustentabilidad en el uso de tierras. Grupo de Análisis de Sistemas Ecológicos / OEA / WRI. San José, Costa Rica, pp.184

[24] WCED (World Commission on Environment and Development) (1987), Our Common Future, Oxford University Press, Oxford.

Citation: Davison G. Mazabe1, Alex R. Caldera. "Self-Sustaining, Irrigated Agriculture and Sustainability. A Study in Southern Guanajuato, Mexico" International Journal of Research in Sociology and Anthropology (IJRSA), vol 4, no. 1, 2018, pp. 24-35. doi:http://dx.doi.org/10.20431/2454-8677.0401004.

Copyright: (C) 2018 Authors. This is an open-access article distributed under the terms of the Creative Commons Attribution License, which permits unrestricted use, distribution, and reproduction in any medium, provided the original author and source are credited. 